The Essence of Software 



\section{The Essence of Software}

Why Concepts Matter for Great Design

Daniel Jackson

PRINCETON UNIVERSITY PRESS • PRINCETON \& OXFORD 
Copyright (C) 2021 by Princeton University Press

Princeton University Press is committed to the protection of copyright and the intellectual property our authors entrust to us. Copyright promotes the progress and integrity of knowledge. Thank you for supporting free speech and the global exchange of ideas by purchasing an authorized edition of this book. If you wish to reproduce or distribute any part of it in any form, please obtain permission.

Requests for permission to reproduce material from this work should be sent to permissions@press.princeton.edu

Published by Princeton University Press

41 William Street, Princeton, New Jersey 08540

6 Oxford Street, Woodstock, Oxfordshire OX20 1TR

press.princeton.edu

All Rights Reserved

ISBN 978-0-691-22538-8

ISBN (e-book) 978-0-691-23054-2

British Library Cataloging-in-Publication Data is available

Editorial: Hallie Stebbins and Kristen Hop

Production Editorial: Jenny Wolkowicki

Jacket design: Emily Weigel

Production: Danielle Amatucci

Publicity: Sara Henning-Stout and Kate Farquhar-Thomson

Copyeditor: Bhisham Bherwani

Interior design: Daniel Jackson

Set in Adobe Arno Pro and Stone Magma using Adobe InDesign

Printed on acid-free paper. $\infty$

Printed in the United States of America

$\begin{array}{llllllllll}10 & 9 & 8 & 7 & 6 & 5 & 4 & 3 & 2 & 1\end{array}$ 


\section{to my parents}


